\title{
Respiratory diseases in hard metal workers: an occupational hygiene study in a factory
}

\author{
Y KUSAKA,${ }^{1}$ K YOKOYAMA, ${ }^{2}$ Y SERA, ${ }^{2}$ S YAMAMOTO, ${ }^{2}$ S SONE, ${ }^{3}$ H KYONO ${ }^{4}$ \\ T SHIRAKAWA, ${ }^{1}$ AND S GOTO ${ }^{1}$
}

From the Department of Hygiene, ${ }^{1}$ Medical School, Osaka University, Osaka City, 530 Japan, National Kinki Chuo Hospital for Chest Diseases, ${ }^{2}$ Osaka City, Department of Radiology, ${ }^{3}$ Medical School, Osaka University, Osaka City, National Institute of Industrial Health, ${ }^{4}$ Osaka City, Japan

\begin{abstract}
A hygiene study of a hard metal factory was conducted from 1981 to 1984 . All workers exposed to hard metal were medically examined and their exposure to cobalt measured. Eighteen employees had occupational asthma related to exposure to hard metal, a prevalence rate of $5.6 \%$. Nine had a positive bronchial provocation test to cobalt and reactions of the immediate, late, or dual type were elicited. Exposure measurements suggest that asthma may be caused by cobalt at a mean time weighted average concentration below $0.05 \mathrm{mg} / \mathrm{m}^{3}$. Only two of the nine individuals with cobalt asthma had a positive patch test to cobalt. Chest radiographs of three workers showed diffuse shadows of category 1 or over. $X$ ray microanalysis of lung biopsy specimens from two of these three workers showed the presence of tungsten, titanium, cobalt, nickel, and some minerals. One of the two was diagnosed as having pneumoconiosis due to exposure to silica in a steel industry and the other was suspected of having pulmonary fibrosis caused by dust generated from the carborundum wheels used to grind hard metal. There were no cases with interstitial pneumonitis in the factory.
\end{abstract}

Hard metal is $90-95 \%$ as hard as diamond. It is used when strength, rigidity, and resistance to heat and wear are needed, such as for the cutting edges of tools, rock drills, and dies, etc.

In Japan research into producing hard metal began in 1928 and hard metal was first on sale in 1931. In 1956 Japan produced only 100 tons of hard metal but in 1978, 1100 tons were produced. Today, Japan is the fourth largest producer of hard metal in the world. There are said to be more than 30 corporations manufacturing hard metal and more than several thousand people are engaged in producing it.

To date few cases of respiratory disorders related to hard metal have been reported in Japan and only one cross sectional field study has been conducted in a hard metal factory. These may be briefly summarised: Ohi found 11 of 38 shapers to have micronodulations in chest $x$ ray examinations in a cross sectional study. ${ }^{1}$ Shirasaki ${ }^{2}$ and Tanizima (personal communication) reported two cases of pulmonary fibrosis in a large hard metal company, one of whom died of respiratory failure. Tanizima also observed 27 workers developing asthma related to exposure to hard metal between 1960 and 1976. Three cases with non-

Accepted 22 July 1985 specific interstitial pneumonitis ${ }^{3-5}$ and one case with giant cell interstitial pneumonitis ${ }^{6}$ were reported. Ikeda et al reported two workers having airways irritation caused by hard metal ${ }^{7}$ and Ebihara described one case with occupational asthma due to cobalt diagnosed by challenge test. ${ }^{8}$ A shaping worker was found on a chest radiograph to have micronodularity associated with primary lung cancer of the giant cell type. $^{9}$

In 1981, for the first time in Japan, both interstitial lung disease and extrinsic asthmatic bronchitis were medicolegally recognised as occupational diseases due to hard metal (article 35 of the enforcement ordinance of the labour standards law.) In 1981 we conducted a cross sectional study in a hard metal factory ${ }^{10-12}$ Since then we have carried out a longitudinal hygiene study to clarify the relation between respiratory disorders and hard metal exposure with particular reference to cobalt since cobalt is known to be the causative agent of asthma in hard metal workers ${ }^{1314}$ and is suspected of causing interstitial pneumonitis. ${ }^{15-19}$

\section{Manufacturing process}

Hard metal is made by a process of powder metal- 
lurgy because tungsten has a high melting point. Metals, such as tungsten, titanium, tantalum, molybdenum, and niobium are blended with carbon and heated to form their respective carbides. Precisely weighed amounts of tungsten carbide and cobalt metal powder, and in the case of some grades small amounts of other carbides, are added and thoroughly mixed in mills. Tungsten carbide constitutes $80-90 \%$ by weight of hard metal and cobalt $5-10 \%$. Cobalt acts as a matrix and nickel is also used as a matrix in some grades. Organic solvents, such as acetone and $\mathrm{n}$-hexane, are added for mixing. The mixture is dried and the organic solvents are driven off. The powder is put into frames made of steel or rubber and then pressed in the desired shapes. The pressed material is presintered in hydrogen furnaces at $500^{\circ} \mathrm{C}$ to $800^{\circ} \mathrm{C}$. Before presintering, pieces are placed on graphite plates and embedded in nitrous aluminium powder. After presintering, the material has the consistency of chalk. It is accurately cut, ground, drilled, or shaped into the required configurations. The shaped material is finally sintered at a temperature of $1550^{\circ} \mathrm{C}$. After sintering the product approaches the hardness of diamond. Hard metal products are sand blasted or shot blasted and then brazed into holders made of iron using fluoride based fluxes. They are then ground with diamond or caborundum wheels; these processes are illustrated in fig 1 .

\section{Subjects}

The hard metal factory we studied was established in the 1950 s when it had only 20 workers. In 1983 about 600 worked in the factory and since the 1950s about 1500 have been in its employ.

In January 1983, 282 workers were exposed to hard metal-12 powder workers, 29 press operators, 21 sintering workers, 46 shapers, 137 grinding workers, two blasting workers, five electron discharging operators, 16 inspectors, 12 researchers, and seven supervisors. Table 1 shows the type of work, the number of workers, their age, and duration of exposure. An additional 37 individuals had been engaged in producing hard metal previously: nine powder workers, two sintering workers, nine shapers, 12 grinding workers, and one inspector. Thus a total of 319 people were or had been exposed to hard metal in January 1983.

\section{Methods}

\section{ENVIRONMENTAL STUDY}

During the observation period between 1981 and 1984 there were no pronounced changes in the production processes or the methods of manufacture. Air samples in the breathing zone were taken on at least

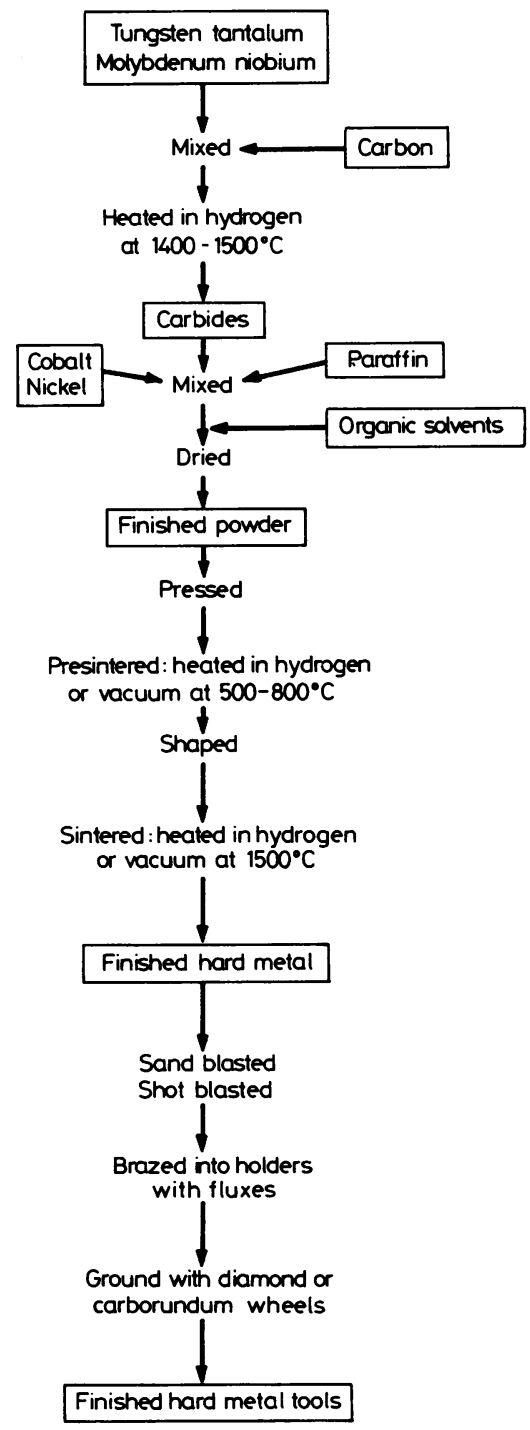

Fig 1 Steps of manufacture.

one working day for every worker exposed to hard metal during this period.

Total dust or mist in the breathing zone was collected individually on a cerullose membrane filter (HA, Millipore) with a dust sampling pump (P-2500, Dupont) at a flow rate of $2.01 / \mathrm{min}$. The mean sampling time was six hours during a workday. The total aerosols were weighted with a balance (H51, Mettler) and combined with a mixture of $2.5 \mathrm{~N} \mathrm{HNO}_{3}$ and $3 \mathrm{~N}$ $\mathrm{HCl}$; their cobalt content was determined using an atomic absorption spectrophotometer (518, Hitachi). 
Table 1 Subjects

\begin{tabular}{lccr}
\hline Work & No of workers & $\begin{array}{l}\text { Age (years) } \\
\text { Mean (range) }\end{array}$ & $\begin{array}{c}\text { Duration of exposure (years) } \\
\text { Mean (range) }\end{array}$ \\
\hline Powder & 12 & $36(25-49)$ & $5(1-13)$ \\
Press & 29 & $39(23-54)$ & $11(1-22)$ \\
Sintering & 21 & $38(19-58)$ & $8(1-21)$ \\
Shaping & 46 & $39(25-56)$ & $9(1-18)$ \\
Grinding & 132 & $37(18-59)$ & $9(1-22)$ \\
Blasting & 2 & $61(54-67)$ & $16(15-17)$ \\
Electron discharging & 5 & $31(18-50)$ & $6(1-13)$ \\
Inspector & 16 & $36(18-52)$ & $14(1-29)$ \\
Developer & 12 & $34(24-49)$ & $8(3-26)$ \\
Supervisor & 7 & $40(29-52)$ & $17(9-28)$ \\
\hline
\end{tabular}

The detection limits for total dust and for cobalt in the air were $0 \cdot 1 \mathrm{mg} / \mathrm{m}^{3}$ and $1 \mu \mathrm{g} / \mathrm{m}^{3}$, respectively.

The aerodynamic size distribution of the airborne particles in a shaping room was estimated with an Andersen sampler (AN-200, Dylec) used at a flow rate of $28.31 / \mathrm{min}$. Hard metal dust in the general air at a height of $1.5 \mathrm{~m}$ was collected on a glass fibre filter (AP, Millipore) placed on each stage in the sampler. Air was inhaled for six hours a day for five consecutive days. Dust on each filter was weighed and its cobalt content determined as noted above.

\section{MEDICAL SURVEY}

All employees who were or had been exposed to hard metal were medically examined each year. The medical examinations consisted of respiratory questionnaires, including a Japanese translation of the British Medical Research Council's questionnaire, full size chest $x$ ray films, spirometry, and a routine physical examination. One of the authors (YK) examined any individual complaining of respiratory symptoms at the factory site. With two chest physicians and a radiologist, all of whom were fully experienced in occupational lung diseases, YK also read all the radiographs. The films were reviewed twice, independently and with no prior knowledge of the status of the individual case. The films were read according to the ILO 1980 International Classification of Radiographs of the Pneumoconioses. ${ }^{20}$ Those findings agreed by all were recorded.

Patients classified as having small opacities of profusion 1 and over were admitted to the National Kinki Chuo Hospital for Chest Diseases and there underwent extensive medical evaluation including transbronchial lung biopsy and blood tests. Lung biopsy specimens were examined by electron microscope and analysed with an analytical electron microscope (H-500, Hitachi) equipped with an energy dispersive $x$ ray microanalyser $(5100$, Kevex) at the National Institute of Industrial Health. The methods used will be described elsewhere.

Peak flow rate was monitored with a Wright's peak flow meter in any worker complaining of attacks of reversible dyspnoea with wheezing. Peak flow rate was recorded in all those examined three times a day $(0600,1200,2100)$ and additionally at any time when attacks occurred.

Total and differential white cell counts, immunoglobulins (IgG, IgA, IgM, IgD, IgE-RIST) and specific IgE antibodies against common environmental allergens (common RASTs), such as house dust, dermatophagoides, pollens of Japanese Cedar, fungi, etc, were measured on all those examined. The normal upper limits of serum IgE-RIST and of eosinophilia were $400 \mathrm{IU} / \mathrm{ml}$ and $5 \%$, respectively. A score of 2 or more on the RAST was regarded as positive. Atopy was defined as an ability to produce IgE antibodies to common inhaled allergens.

A patch test using $2.0 \% \mathrm{CoCl}_{2}$ in petrolatum was undertaken in all subjects with readings taken at 48 and 72 hours. Findings agreed by two dermatologists were recorded according to the classification recommended by the International Contact Dermatitis Research Group. ${ }^{21}$

Some individuals with asthma were admitted to hospital where they underwent a bronchial provocation test with cobalt using the method described by Roto. ${ }^{22}$ A subject was asked first to inhale $2 \mathrm{ml}$ of $0 \cdot 1 \%$ cobalt chloride solution. If his bronchi did not react within one hour with a decrease in $\mathrm{FEV}_{1}$ of more than $15 \%$ he then inhaled $2 \mathrm{ml}$ of $1.0 \% \mathrm{CoCl}_{2}$. The test was considered positive if $\mathrm{FEV}_{1}$ decreased by more than $15 \%$ within one day after the test. A control test was performed using $2 \mathrm{ml}$ of physiological saline solution.

\section{Results}

\section{ENVIRONMENTAL STUDY}

Table 2 shows the number of air samples, the number of workers in each group, and the cobalt concentrations (mean, standard deviation, range) for each group of workers. Press operators are divided into two groups in respect of cobalt exposure levels. One 
Table 2 Cobalt exposure concentrations in each group

\begin{tabular}{|c|c|c|c|c|}
\hline \multirow[t]{2}{*}{ Work } & \multirow{2}{*}{$\begin{array}{l}\text { No of } \\
\text { workers }\end{array}$} & \multirow{2}{*}{$\begin{array}{l}\text { No of } \\
\text { samples }\end{array}$} & \multicolumn{2}{|l|}{ Cobalt concentrations } \\
\hline & & & $M e a n \pm S D$ & Range \\
\hline $\begin{array}{l}\text { Powder } \\
\text { Press: }\end{array}$ & 12 & 38 & $688 \pm 1075 \mu \mathrm{g} / \mathrm{m}^{3}$ & $6-6388 \mu \mathrm{g} / \mathrm{m}^{3}$ \\
\hline $\begin{array}{l}\text { Rubber } \\
\text { Machine } \\
\text { Sintering } \\
\text { Shaping } \\
\text { Grinding: }\end{array}$ & $\begin{array}{r}4 \\
25 \\
21 \\
47\end{array}$ & $\begin{array}{r}19 \\
27 \\
38 \\
129\end{array}$ & $\begin{aligned} 473 & \pm 654 \\
85 & \pm 95 \\
28 & \pm 26 \\
126 & \pm 191\end{aligned}$ & $\begin{array}{l}48-2905 \\
4-407 \\
2-145 \\
6-1155\end{array}$ \\
\hline $\begin{array}{l}\text { Grinding: } \\
\text { Wet } \\
\text { Dry } \\
\text { Electron discharging } \\
\text { Blasting }\end{array}$ & $\begin{array}{r}131 \\
1 \\
5 \\
2\end{array}$ & $\begin{array}{r}205 \\
2 \\
5 \\
5\end{array}$ & $\begin{aligned} & 53 \pm 106 \\
& 1292 \pm 179 \\
& 4 \pm 1 \\
& 3 \pm 1\end{aligned}$ & $\begin{array}{c}11-1247 \\
1113-1471 \\
1-5 \\
1-4\end{array}$ \\
\hline
\end{tabular}

dry grinding worker was exposed to an enormous amount of cobalt. After measurements, a local ventilation system was installed for him and his cobalt level then decreased to $14 \mu \mathrm{g} / \mathrm{m}^{3}$.

In the shaping room the respirable fraction $(<7.0 \mu \mathrm{m})$ formed $75 \%$ of the total dust; the cobalt concentration in the respirable dust was $68 \%$ of the total.

\section{MEDICAL SUR VEY}

\section{Occupational asthma}

Eighteen employees were found to have occupational asthma related to exposure to hard metal. All initially developed asthmatic attacks after employment in the hard metal industry. All showed a time relation between attacks of asthma and exposure to hard metal as follows: attacks disappeared or decreased at weekends and during holidays; the symptoms partially or completely remitted after wearing respirators or installing exhaust ventilation systems; asthma was relieved after a stay in hospital but recurred after resumption of work; attacks improved after individuals were transferred to other less dusty or non-dusty workplaces; and asthma disappeared after leaving the factory.

In January 1983 the prevalence rate of occupational asthma was $5.6 \%$ (18 of 319). During the observation period (1981-4) two of the 18 cases newly developed asthma; the remaining 16 had had asthma before the study.

Eight of the 18 sufferers with asthma were powder workers, one a sintering worker, three were shapers, and six were grinding workers. The latent period ranged from three months to ten years; seven workers developed asthma, mainly of the nocturnal type, two to three years after their initial exposure to hard metal. Chronic bronchitis occurred after the onset of asthma in five workers, resulting in an asthmatic bronchitis.

Nine of the 18 had positive bronchial provocation tests with cobalt $\left(2 \mathrm{ml}\right.$ of $\left.1.0 \% \mathrm{CoCl}_{2}\right)$. The remaining nine refused to take the tests. Two of the nine positive cases had dual reactions - combined immediate and late responses - to inhaled cobalt, two immediate and five late. The exact mean cobalt concentration to which four cases were exposed was $18 \mu \mathrm{g} / \mathrm{m}^{3}$, $24 \mu \mathrm{g} / \mathrm{m}^{3}$, over $31 \mu \mathrm{g} / \mathrm{m}^{3}$, and over $1203 \mu \mathrm{g} / \mathrm{m}^{3}$. For the remaining five cases, the exposure levels could not be determined, since they had already been transferred to other works. Only two of the nine individuals had a positive patch test to cobalt.

All 18 cases are described briefly in the appendix and in table 3 .

\section{Diffuse shadows in chest radiographs}

Three workers had diffuse shadows on their chest radiographs with a profusion of 1 or more. One with a chest radiograph of category 2 , was diagnosed as having pneumoconiosis caused by minerals to which he had been exposed in a steel industry. The second case was suspected of having pulmonary fibrosis related to dust generated from grinding wheels containing carborundum and silica. The third case could not be diagnosed because he declined a lung biopsy. (The case histories appear as 19-21 in the appendix.)

\section{Interstitial lung disease}

Symptoms such as dry cough, progressive dyspnoea, fever, weight loss, and general fatigue, and diffuse reticular or linear shadows on chest radiographs associated with restrictive ventilatory disorders have been reported in workers with interstitial pneumonitis related to hard metal exposure. ${ }^{1423-27}$ Among the workers examined here these symptoms were not detected nor were abnormalities on chest radiographs associated with a restrictive defect observed.

\section{Discussion}

In the United States, United Kingdom, West 
Table 3 Cases with occupational asthma due to hard metal

\begin{tabular}{|c|c|c|c|c|c|c|c|c|c|}
\hline Case & $\begin{array}{l}\text { Age } \\
\text { (years) }\end{array}$ & Atopy & Work & $\begin{array}{l}\text { Cobalt } \\
\text { concentration } \\
\left(\mu g / m^{3}\right) \\
M \pm S D \text { range })\end{array}$ & $\begin{array}{l}\text { Latent } \\
\text { period }\end{array}$ & $\begin{array}{l}\text { Positive } \\
\text { cobalt } \\
\text { provocation }\end{array}$ & $\begin{array}{l}\text { Positive } \\
\text { cobalt } \\
P T\end{array}$ & $\begin{array}{l}\text { High } \\
\text { IgE } \\
(I U / \mathbf{m l})\end{array}$ & $\begin{array}{l}\text { Eosinophilia } \\
(\%)\end{array}$ \\
\hline $\begin{array}{l}1 \\
2\end{array}$ & $\begin{array}{l}24 \\
28\end{array}$ & Yes & $\begin{array}{l}\text { Powder } \\
\text { Powder }\end{array}$ & & $\begin{array}{l}1 \mathrm{y} \\
2 \mathrm{~m}\end{array}$ & $\begin{array}{l}\text { Yes } \\
\text { (immediate) }\end{array}$ & Yes & $\begin{array}{l}\text { Yes } \\
(618)\end{array}$ & $\begin{array}{l}\text { Yes } \\
(9 \cdot 0)\end{array}$ \\
\hline 3 & 38 & & Powder & $>1203$ & $3 \mathrm{~m}$ & $\begin{array}{l}\text { Yes } \\
\text { (dual type) }\end{array}$ & & & \\
\hline 4 & 44 & & Powder & & $5 \mathrm{~m}$ & & & $\begin{array}{l}\text { Yes } \\
(974)\end{array}$ & \\
\hline $\begin{array}{l}5 \\
6\end{array}$ & $\begin{array}{l}40 \\
41\end{array}$ & & $\begin{array}{l}\text { Powder } \\
\text { Powder }\end{array}$ & & $\begin{array}{l}3 \mathrm{~m} \\
2 \mathrm{y}\end{array}$ & $\begin{array}{l}\text { Yes } \\
\text { (immediate) }\end{array}$ & & & \\
\hline 7 & 42 & & Powder & & $6 \mathrm{~m}$ & & Yes & & $\begin{array}{l}\text { Yes } \\
(7 \cdot 7)\end{array}$ \\
\hline 8 & 40 & & Powder & 331 & $2 y$ & & Yes & $\begin{array}{l}\text { Yes } \\
(1063)\end{array}$ & \\
\hline 9 & 44 & & Sintering & $\begin{array}{l}24 \pm 11 \\
(8-48)\end{array}$ & $10 y$ & $\begin{array}{l}\text { Yes } \\
\text { (late type) }\end{array}$ & & & \\
\hline 10 & 31 & Yes & Shaping & & $1 \mathrm{y}$ & $\begin{array}{l}\text { Yes } \\
\text { (late type) }\end{array}$ & & & $\begin{array}{l}\text { Yes } \\
(8 \cdot 0)\end{array}$ \\
\hline 11 & 47 & & Shaping & $\begin{array}{l}158 \pm 127 \\
(31-436)\end{array}$ & $3 \mathrm{~m}$ & $\begin{array}{l}\text { Yes } \\
\text { (late type) }\end{array}$ & & & \\
\hline 12 & 51 & & Shaping & & $4 \mathrm{~m}$ & & & & \\
\hline $\begin{array}{l}13 \\
14 \\
15\end{array}$ & $\begin{array}{l}40 \\
41 \\
36\end{array}$ & & Grinding & $>18$ & $\begin{array}{l}2 \text { y } 6 \mathrm{~m} \\
3 \text { y }\end{array}$ & & & & \\
\hline 10 & 36 & Yes & Grinding & $>31$ & $4 y$ & $\begin{array}{l}\text { Yes } \\
\text { (late type) }\end{array}$ & & $\begin{array}{l}\text { Yes } \\
(588)\end{array}$ & $\begin{array}{l}\text { Yes } \\
(11 \cdot 6)\end{array}$ \\
\hline 16 & 39 & & Grinding & $\begin{array}{l}18 \pm 8 \\
(5-29)\end{array}$ & 1 y & $\begin{array}{l}\text { Yes } \\
\text { (late type) }\end{array}$ & & & \\
\hline $\begin{array}{l}17 \\
18\end{array}$ & $\begin{array}{l}38 \\
28\end{array}$ & Yes & $\begin{array}{l}\text { Grinding } \\
\text { Grinding }\end{array}$ & & $\begin{array}{l}1 \mathrm{y} \\
3 \mathrm{~m}\end{array}$ & $\begin{array}{l}\text { Yes } \\
\text { (dual type) }\end{array}$ & Yes & $\begin{array}{l}\text { Yes } \\
(1500)\end{array}$ & $\begin{array}{l}\text { Yes } \\
(12 \cdot 0)\end{array}$ \\
\hline
\end{tabular}

PT $=$ Patch test.

Germany, Switzerland, and Sweden the hygiene standard for cobalt is $0.1 \mathrm{mg} / \mathrm{m}^{3}$. In Japan, as reported in this study, many workers have been exposed to cobalt at a concentration in excess of $0.1 \mathrm{mg} / \mathrm{m}^{3}$ mainly because the Japan Association of Industrial Health has not yet proposed to industry a threshold limit for cobalt.

In May 1985 a new factory for powder mixing was constructed and the old powder mixing area was closed in the industry that we examined. In the new factory dust collecting ventilation systems were installed and as a result the mean cobalt exposure for all powder workers decreased to $175 \mu \mathrm{g} / \mathrm{m}^{3}$, a quarter of that in the old factory.

As all powder workers and some shaping workers wore respirators, the actual uptake of cobalt was lower than the content of cobalt in the breathing zone air. ${ }^{28}$ Grinding hard metal is done mainly with cutting fluids in which cobalt is dissolved. As coolant fluids are used repeatedly, their concentration of cobalt tends to increase. Collecting the mist from cutting fluids is much more difficult and much less economical than collecting hard metal dust, so that only a limited number of grinding machines were provided with local exhaust ventilation systems.
We could not perform bronchial provocation tests with cobalt on all the cases of asthma and we have no information on the possible immunological mechanism of asthma caused by cobalt. Thus we have established empirical criteria for diagnosing occupational asthma in hard metal workers. Any subject who develops asthma after employment in the hard metal industry and shows the correlation between the asthma and a change of exposure to hard metal or any case with a history of asthma in whom the asthma is aggravated after employment and shows the time relation of symptoms and exposure to hard metal has been defined as having occupational asthma. The criteria may result in both false positive and false negative cases. An overestimation of the time course of the symptoms may give false positive results. On the other hand, some workers with bronchial hypersensitivity may react not only to occupational substances but also to non-occupational factors, so that attacks may not appear to be related to their exposure to hard metal.

We did not report five cases with asthma in this study. Two who were atopic developed asthma after employment but we could detect no relation between their asthma and exposure to hard metal. In the third 
case asthma occurred after exposure to hard metal but disappeared spontaneously without treatment. The fourth case had had atopic asthma before he was employed in the industry but the symptoms had not become aggravated. The last case had atopic asthma before starting to grind hard metal and his asthma recurred three years after he was employed. There was no relation between the asthma and his exposure and a bronchial provocation test with cobalt was negative, although challenge with extracts of Dermatophagoides pteronyssinus was positive. We did not consider these subjects to be suffering from occupational asthma.

The prevalence of occupational asthma was $5.6 \%$; the incidence rate was not obtained, however, since many workers with the condition (cases 3 and 8, for example) had left the industry because of their illness. Coates et al reported that the prevalence rate of occupational asthma was $0.6 \%$ in a large hard metal factory with the work force of $1500,{ }^{3}$ but the criteria for diagnosing the condition, the characteristics of the subjects, their symptoms, and their exposure levels were not described.

Some workers with occupational asthma did not completely recover even after they were transferred to non-dusty work. This has also been observed in other cases of occupational asthma caused by cobalt and western cedar. ${ }^{1429}$ Moreover, in some cases, the recurrence of asthma has led to a fixed obstructive ventilatory defect even when asthma attacks were absent. We think it necessary, therefore, to detect immediately any individual developing asthma and to remove him from dusty work as soon as possible. On the basis of this study, as reported previously by Coates et al $^{13}$ and Davison et al, ${ }^{14}$ cobalt can be shown to be the causative agent of occupational asthma in hard metal workers. Provocation tests with cobalt showed three types of reactions: an immediate type (cases 2, 6), a late type (cases 9, 10, 11, 15, 16) and a dual type with both immediate and late reactions (cases 3,18 ). The second type has also been described by Coates et al and the third by Davison et al. ${ }^{1314}$ The occurrence of late reactions can implicate nocturnal attacks in workers with occupational asthma due to hard metal. The possible immunological mechanisms concerned remain to be clarified.

Measurements of exposure levels in workers with cobalt asthma (cases 11, 16) suggest that the condition may be caused at a mean time weighted average concentration below $0.05 \mathrm{mg} / \mathrm{m}^{3}$. In Finland asthma has been reported to occur in metal refinery workers at a cobalt concentration of less than $0.1 \mathrm{mg} / \mathrm{m}^{3} .^{22}$ Further field studies are needed to see if there is a dose relation between levels of cobalt exposure and the onset of asthma. Additionally, not only the time weighted average but also the ceiling or short time exposure limit, which may be concerned with sensitisation, should be determined for cobalt.

Rüttner and Furrer described the histological findings of necropsied lungs and their analytical results in two grinding workers who had nodular shadows on their chest radiographs. ${ }^{30}$ One had worked with hard metal for 22 years and the other for 36 . In the lungs were partially fibrosed, star shaped, dust containing elementary nodules similar to those seen in a mixed dust silicosis such as foundry worker's silicosis. The nodules were surrounded by perifocal emphysema. Rüttner and Furrer emphasised the role of carborundum and silica derived from the grinding wheels in the development of the pulmonary fibrosis.

In case 20 the transbronchial lung biopsy specimens were so small in volume that we could not see the presence of silicotic nodules. The chest radiograph was similar to that reported by Rüttner and Furrer and the pulmonary histology was also consistent with that reported by them. ${ }^{30}$ This worker had probably inhaled an excessive amount of dust because he ground hard metal using dry carborundum wheels without ventilation.

We could not diagnose case 21 accurately but the presentation was not consistent with interstitial pneumonitis and old pulmonary tuberculosis might be involved.

In the factory we consider there was no case with interstitial pneumonitis. This differs completely from some previous reports. ${ }^{231-35}$ Miller et al showed that three hard metal workers developed interstitial lung diseases with cobalt levels of $0 \cdot 1$ to $0.3 \mathrm{mg} / \mathrm{m}^{3} .{ }^{35}$ In our factory many workers had been exposed to cobalt concentrations much higher than $0.1 \mathrm{mg} / \mathrm{m}^{3}$ and workers with interstitial pneumonitis might have left the industry because of their illness. We were told by the company, however, that there had been no cases with interstitial lung disease.

In a large hard metal corporation in the United Kingdom with a work force of 1000 employees no workers with interstitial pneumonitis were found. ${ }^{32}$ Reviewing this report and our study, the incidence rate and the prevalence rate of interstitial lung disease related to hard metal are probably low. Almost all field investigations have been cross sectional and some have examined only a limited number of the total at risk. A thorough epidemiological study of hard metal industries is therefore needed.

We are grateful to Dr Minoru Tashiro and Dr Kenji Sato of the department of dermatology, Medical School, Osaka University, for reading the cobalt patch tests. 


\section{Appendix}

Case 1-Born in 1933, smoker since age 20. Father had asthma. Started powder mixing in the industry at age 23 and developed nocturnal asthma one year after starting work. Three years later transferred to non-dusty work and the asthma completely disappeared.

Case 2-Born in 1941, smoker from age 20 to 25. Father had asthma. Employed as an inspector at age 19. In 1969 developed nocturnal asthma two months after transfer to powder department. Attacks improved at weekends and during holidays. Five years later began to work as an inspector again and asthma partially remitted. In 1985 underwent bronchial provocation test with cobalt. A $27 \%$ fall in FEV $_{1}$ occurred 10 minutes after inhalation of $1 \% \mathrm{CoCl}_{2}$. High IgE-RIST of $618 \mathrm{IU} / \mathrm{ml}$ and eosinophilia of $9 \%$ seen in an attack. Common RASTs were positive. He had a positive patch test with cobalt 72 hours after patch.

Case 3-Born in 1932, a non-smoker. Had inhaled carbon dust for 10 years. Employed as a powder worker at age 38 . Nocturnal asthma occurred three months after employment. Asthma improved at weekends and during holidays. Attacks decreased after improvements to the manufacturing process and also after wearing a respirator. In 1982 his cobalt concentration was $1203 \mu \mathrm{g} / \mathrm{m}^{3}$ on average (number of samples 3, SD $482 \mu \mathrm{g} / \mathrm{m}^{3}$, range $551-1700 \mu \mathrm{g} / \mathrm{m}^{3}$ ). In 1983 left the industry and the asthma completely disappeared. Chronic bronchitis occurred after the onset of asthma. In 1983, three months after leaving the factory, he had a bronchial provocation test with cobalt which produced a dual reaction (a $17 \%$ fall in FEV $_{1}$ at 15 minutes and a $28 \%$ fall at 90 minutes) after inhaling $2 \mathrm{ml}$ of $1 \% \mathrm{CoCl}_{2}$. Control test was negative. Neither high immunoglobulins nor eosinophilia were detected.

Case 4-Born in 1928, a smoker. After working as an electric welder for six years began to work with hard metal powder at age 44. Developed asthma three months after starting work. Seven years later transferred to the shaping department. Asthma partially remitted. In shaping exposed to a cobalt concentration of $43 \mu \mathrm{g} / \mathrm{m}^{3}$ on average $\left(\mathrm{n}=4\right.$, SD $24 \mu \mathrm{g} / \mathrm{m}^{3}$, range $9-62 \mu \mathrm{g} / \mathrm{m}^{3}$ ). IgE was increased to $974 \mathrm{IU} / \mathrm{ml}$ but common RASTs were negative.

Case 5-Born in 1953, a smoker. Employed as a powder worker in 1973. Three months later nocturnal asthma appeared. Free of attacks when off work. Changed to shaping and asthma completely disappeared. In shaping department the mean cobalt concentration was $104 \mu \mathrm{g} / \mathrm{m}^{3}\left(\mathrm{n}=5, \mathrm{SD} 36 \mu \mathrm{g} / \mathrm{m}^{3}\right.$, range $\left.66-153 \mu \mathrm{g} / \mathrm{m}^{3}\right)$.

Case 6-Born in 1933, a smoker with urticaria of unknown origin. Started powder handling in the industry at age 41 . Two years after starting work developed nocturnal asthma. Symptom free at weekends. Six years later transferred to sintering department and attacks disappeared. Chronic bronchitis followed asthma. In sintering he had cobalt concentration of $28 \mu \mathrm{g} / \mathrm{m}^{3}$ on average $\left(\mathrm{n}=3\right.$, SD $5 \mu \mathrm{g} / \mathrm{m}^{3}$, range $23-33 \mu \mathrm{g} / \mathrm{m}^{3}$ ). A challenge test was performed with $2 \mathrm{ml}$ of $1 \%$ $\mathrm{CoCl}_{2}$ which showed immediate reaction (a $35 \%$ fall in $\mathrm{FEV}_{1}$ at 15 minutes).

Case 7-Born in 1936, his urticaria resulted from tenpura or deep fried food. Smoked from age 20 to 45 . Exposed to cement and asbestos dust for three years before working in hard metal industry as a powder worker in 1978. Complained of asthma six months after working with hard metal. Symptoms cleared at weekends and holidays. Chronic bronchitis appeared secondary to asthma. Three years later started working as a sintering worker. Asthma partially remitted but still remained. Attacks absent at weekends but occurred on working days (fig 2 ). In sintering exposed to a mean cobalt concentration of $25 \mu \mathrm{g} / \mathrm{m}^{3}\left(\mathrm{n}=2\right.$, SD $14 \mu \mathrm{g} / \mathrm{m}^{3}$, range $\left.11-38 \mu \mathrm{g} / \mathrm{m}^{3}\right)$. Differential white cell count showed an eosinophilia of $7.7 \%$ but IgE did not increase during attacks. Patch test with cobalt was positive. Case 8-Born in 1941, a smoker. Employed as a powder worker at age 38. Two years later developed nocturnal asthma. Personal air sample showed cobalt concentration of $331 \mu \mathrm{g} / \mathrm{m}^{3}$. Asthma cleared in hospital and recurred after returning to work. This course was repeated a few times. High IgE was detected during attacks but

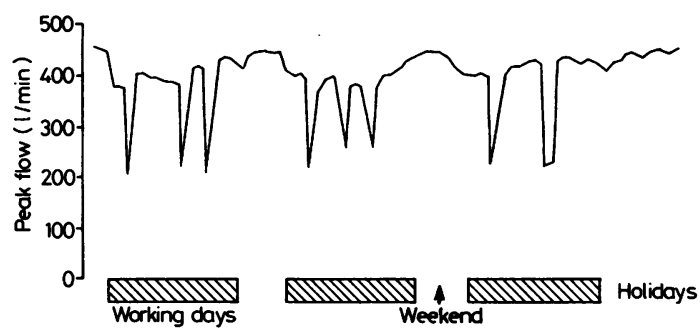

Fig 2 Peak flow rate record of a hard metal worker.

common RASTs were negative. Left the industry and the asthma completely remitted. Patch test was positive to cobalt.

Case 9-Born in 1933, started to smoke at age 20. Began work as a sintering worker in 1967. Ten years later developed nocturnal asthma. In 1982 stopped smoking. Chronic bronchitis occurred after onset of asthma. Exposed to a mean cobalt concentration of $24 \mu \mathrm{g} / \mathrm{m}^{3}\left(\mathrm{n}=12, \mathrm{SD} 11 \mu \mathrm{g} / \mathrm{m}^{3}\right.$, range $\left.8-48 \mu \mathrm{g} / \mathrm{m}^{3}\right)$. Working conditions stable from 1967 to 1984 . Bronchial provocation test with

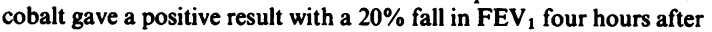
inhalation of $1 \% \mathrm{CoCl}_{2}$ (fig 3). Neither high IgE nor positive common RASTs were detected.

Case 10-Born in 1931, a smoker. Grandfather and mother had asthma. Since 1961, had worked as a shaper and developed asthma one year later. Transferred to grinding department but asthma continued. When he ground hard metal, the cobalt exposure level was $82 \mu \mathrm{g} / \mathrm{m}^{3}$ on average $\left(\mathrm{n}=2\right.$, SD $9 \mu \mathrm{g} / \mathrm{m}^{3}$, range $\left.73-90 \mu \mathrm{g} / \mathrm{m}^{3}\right)$. Asthma cleared during a stay in hospital but attacks appeared after resuming work. At age 53, changed to work free from hard metal exposure. Nevertheless, asthma only partially remitted. Chronic bronchitis occurred after onset of asthma. In provocation test a $38 \%$ decrease in $\mathrm{FEV}_{1}$ at one hour followed the inhalation of $1 \% \mathrm{CoCl}_{2}$. In the provoked attack his eosinophilia increased from $5 \%$ to $8 \%$. Case 11-Born in 1933, a smoker. Started shaping presintered hard metal in 1980. Three months later developed nocturnal asthma. Attacks improved after wearing a respirator and were relieved at

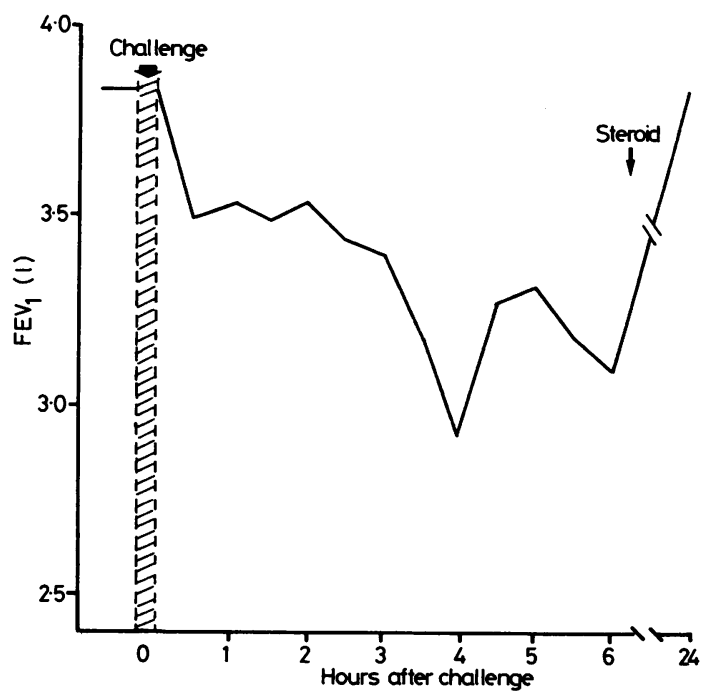

Fig 3 Late reaction to inhalation challenge with $2 \mathrm{ml} \mathrm{of} 1 \%$ $\mathrm{CoCl}_{2}$. 
weekends. His PF record was similar to that of case 7. During observation period, mean cobalt concentration was $158 \mu \mathrm{g} / \mathrm{m}^{3}$ $\left(\mathrm{n}=8\right.$, SD $127 \mu \mathrm{g} / \mathrm{m}^{3}$, range $\left.31-436 \mu \mathrm{g} / \mathrm{m}^{3}\right)$. Working environment had remained unchanged since 1980 . Had a late reaction provoked by inhaling $1 \% \mathrm{CoCl}_{2}$ (a $20 \%$ fall at 3 hours 15 minutes). Neither immunoglobulins nor common RASTs were raised; patch test with cobalt gave a negative result.

Case 12 - Born in 1932, a smoker. Mother had a history of asthma. Had worked as a welder for seven years and began working as a wet grinder at age 41 when his exposure level was $27 \mu \mathrm{g} / \mathrm{m}^{3}$. Ten years after first employment transferred to shaping department and asthma occurred four months later. Attacks cleared at weekends. Exposed to cobalt at a concentration of $893 \mu \mathrm{g} / \mathrm{m}^{3}$ on average $(\mathrm{n}=3$, SD $278 \mu \mathrm{g} / \mathrm{m}^{3}$, range $602-1155 \mu \mathrm{g} / \mathrm{m}^{3}$ ). Local exhaust ventilation was attached to the shaping machine and his cobalt exposure decreased to $198 \mu \mathrm{g} / \mathrm{m}^{3}$ and the asthma subsided. Figure 4 shows relation of asthmatic attacks and exposure to hard metal.

Case 13-Born in 1935, a smoker with urticaria of unknown origin. Employed as a wet grinding worker at age 38 . Two and a half years after employment developed nocturnal asthma; symptoms improved at weekends. Six months later after installation of a mist collecting system asthma completely remitted. Measurement of personal. exposure showed his cobalt concentration to be $18 \mu \mathrm{g} / \mathrm{m}^{3}$ on average $\left(\mathrm{n}=2\right.$, SD $4 \mu \mathrm{g} / \mathrm{m}^{3}$, range $\left.14-21 \mu \mathrm{g} / \mathrm{m}^{3}\right)$.

Case 14-Born in 1936, had urticaria of unknown origin. Smoker for only one year. Had inhaled glass dust and dust from grinding wheels for 18 years. Had started grinding hard metal with cutting fluid at age 38. Nocturnal asthma occurred three years after starting grinding. Three years later changed to work with no exposure to hard metal and asthma partially remitted. Chronic bronchitis followed asthma. Case 15-Born in 1941, smoker from age 15 to 20. Father had asthma. Began grinding at age 32. Four years later a new efficient grinding machine was installed and asthma appeared. Two years after onset of asthma, a mist collecting system was attached to machine after which asthma partially improved, although attacks still occurred at nights when he used the machine without the ventilation. With exhaust ventilation control, he had a mean exposure to cobalt of $31 \mu \mathrm{g} / \mathrm{m}^{3}\left(\mathrm{n}=3\right.$, SD $8 \mu \mathrm{g} / \mathrm{m}^{3}$, range $\left.21-44 \mu \mathrm{g} / \mathrm{m}^{3}\right)$. High IgE levels and eosinophilia were seen using attacks and common RASTs were positive. Bronchial provocation test with $1 \% \mathrm{CoCl}_{2}$ of $2 \mathrm{ml}$ gave a positive late reaction (a fall in $\mathrm{FEV}_{1}$ at 5 hours 30 minutes).

Case 16-Born in 1935, had urticaria. Pulmonary tuberculosis associated with paragonimiasis occurred at age 21 . Had been treated with antituberculous drugs and 4,6-dichlorophenol for two years and recovered fully. Had smoked from age 35 to 44 . Started grinding hard metal at age 38 and developed nocturnal asthma one year later. Attacks cleared in hospital but reappeared after resumption of work. He had a mean exposure to cobalt of $18 \mu \mathrm{g} / \mathrm{m}^{3}\left(\mathrm{n}=9\right.$, SD $8 \mu \mathrm{g} / \mathrm{m}^{3}$, range $5-29 \mu \mathrm{g} / \mathrm{m}^{3}$ ). Working environment had remained unchanged since 1973. Transferred to non-dusty work in 1984 and asthma partially remitted. An eosinophilia of $20 \%$ seen during an attack. Neither high immunoglobulins nor positive common RASTs were observed. In 1984, after changing work, challenge test was per-

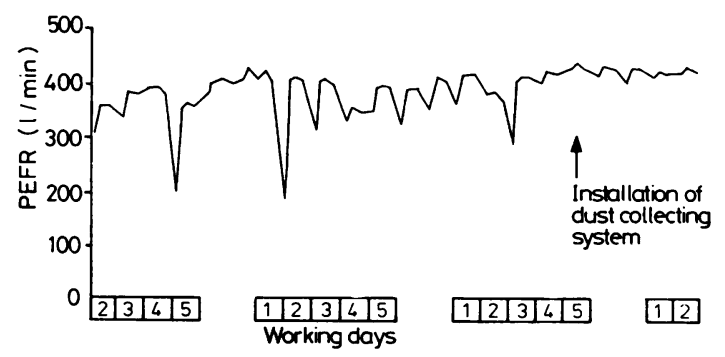

Fig 4 PEFR of a shaping worker with asthma related to work.

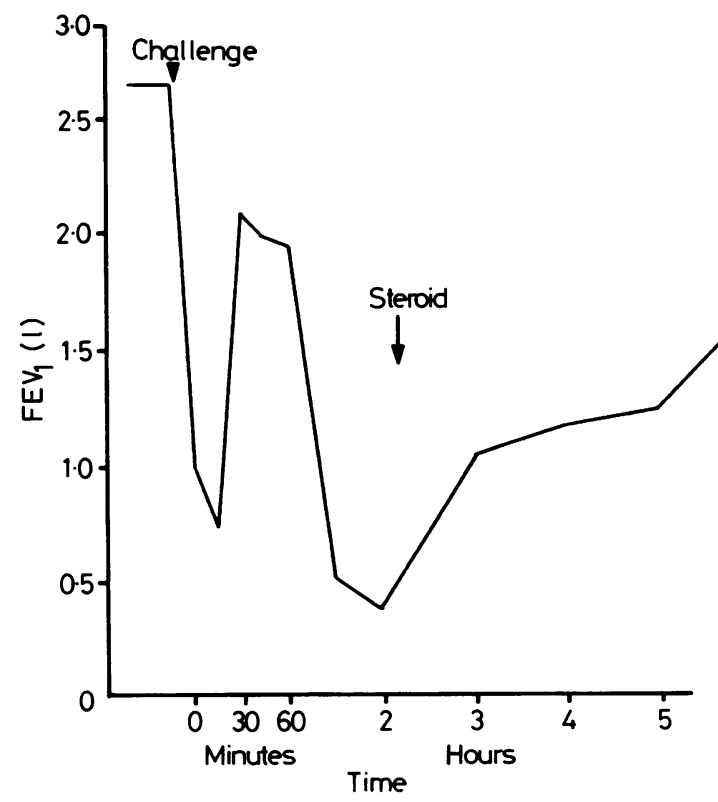

Fig 5 Combined immediate and non-immediate (dual) asthmatic reaction to cobalt $\left(1 \% \mathrm{CoCl}_{2}\right)$.

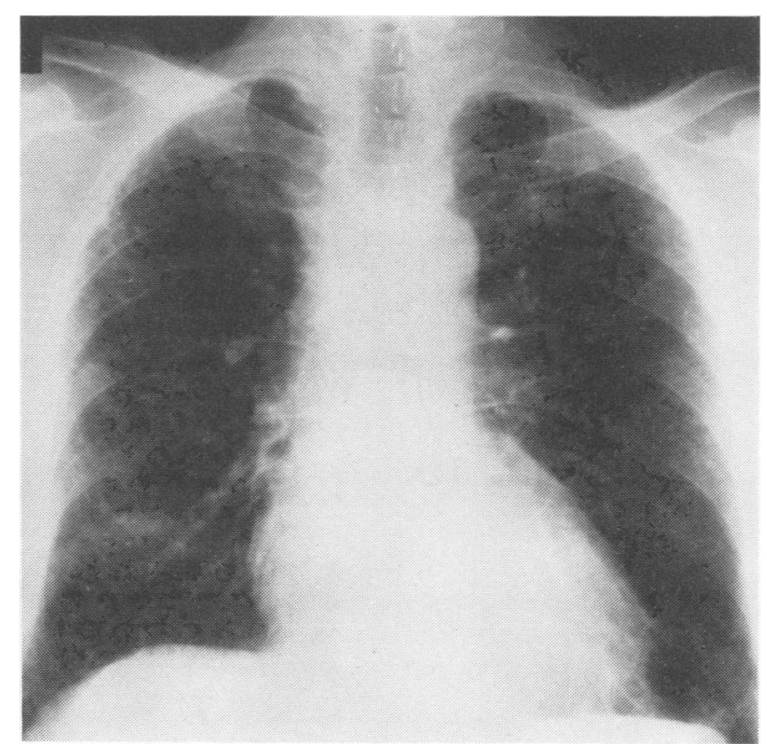

Fig 6 Chest $x$ ray film showing reticulonodulations (profusion 2/2, shape size $s / q$ ). 


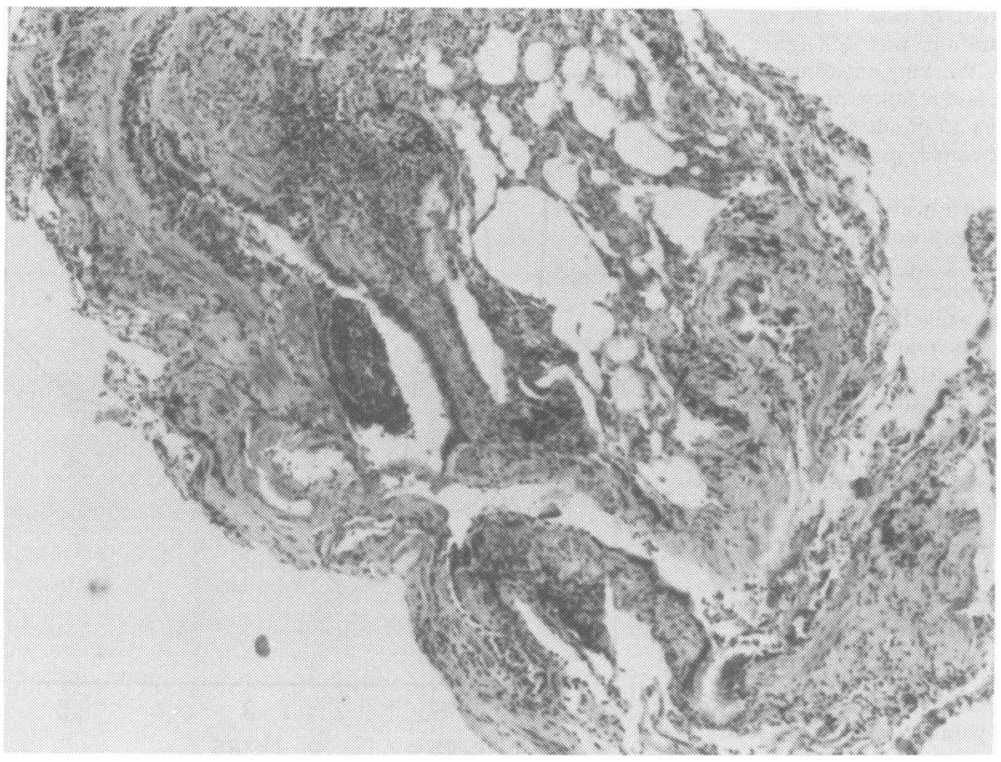

Fig 7 Peribronchial and perivascular fibrosis with deposited black particles and peribronchiolar lymphoid cell aggregation. $(H E \times 40)$.

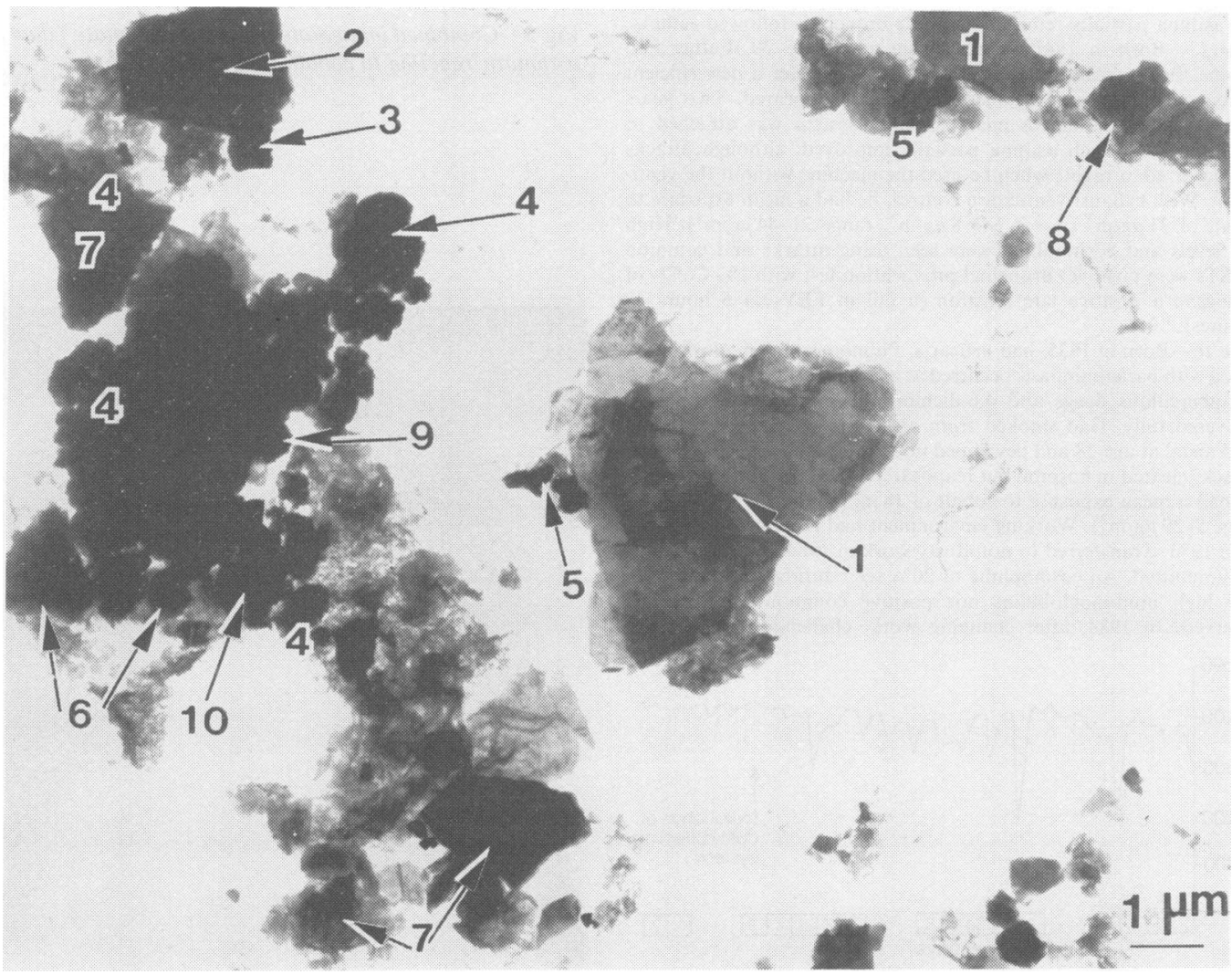

Fig 8 Electron micrograph of mineral particles deposited in lung biopsy specimen of case 19. Sample was prepared from deparaffinised section of $4 \mu \mathrm{m}$ thickness by carbon extraction method. Points indicated by arrows were analysed and identified as follows: (1) biotite, Ti, (2) oligoclase, (3) Fe, Co, (4) Ti, Fe, Co, (5) Fe, (6) Fe, muscovite, (7) quartz, (8) kaolin, $\mathrm{Fe}, \mathrm{Co}$, (9) kaolin, Ti, Fe, Co, and (10) W, Ti, Fe, Co, Ni. 


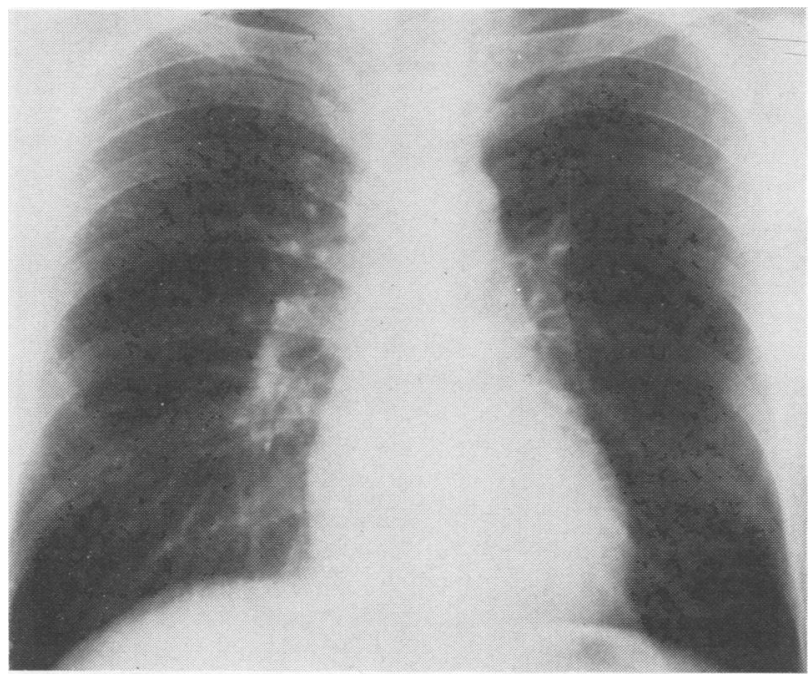

Fig 9 Chest $x$ ray film showing small rounded opacities (profusion 1/2, shape size $p / q$ ).

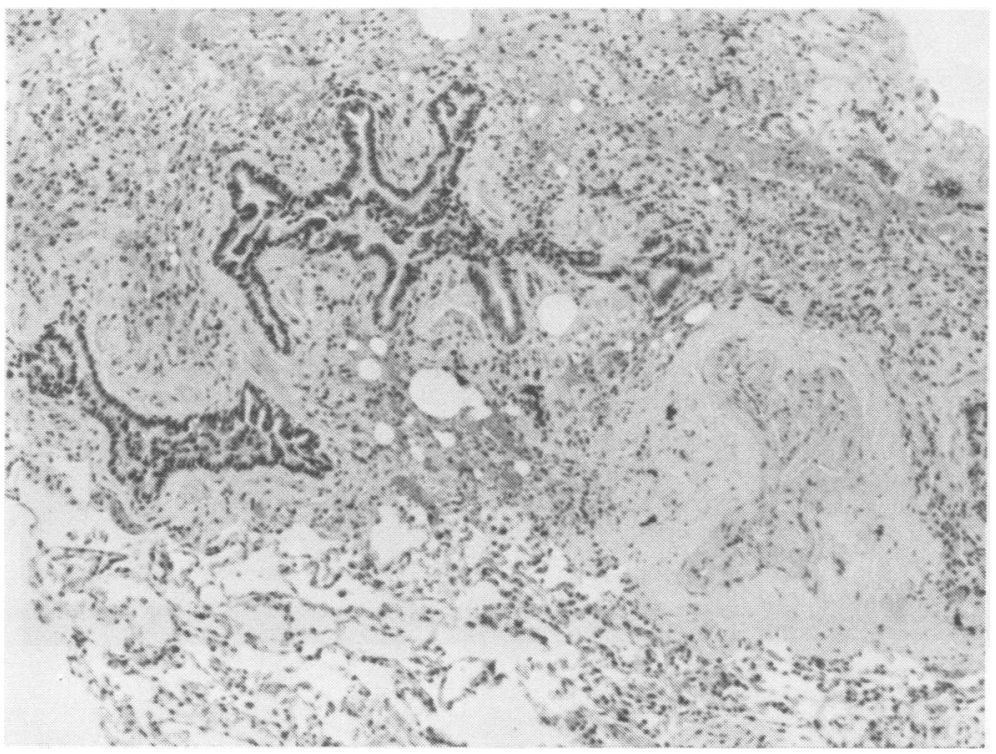

Fig 10 Peribronchiolar fibrosis with dust deposition and thickening of arteriole intima $(H E \times 40)$.

formed. While control test with physiological saline solution gave a $14 \%$ fall in $\mathrm{FEV}_{1}$ at six hours, asthma of late type (a $33 \%$ fall in $\mathrm{FEV}_{1}$ at six hours) was provoked by $1 \% \mathrm{CoCl}_{2}$.

Case 17-Born in 1942, a smoker. Began wet grinding at age 37 and developed nocturnal asthma one year later. Assigned to work as an inspector when the asthma completely disappeared.

Case 18-Born in 1950, had history of urticaria. Smoker from age 22 to 29. Employed as a wet grinder in industry at 28. Three months later developed nocturnal asthma which improved at weekends. Transferred to non-dusty work and asthma partially remitted. Chronic bronchitis followed asthma. In 1983 bronchial provocation test was performed and a dual type of response followed challenge by $2 \mathrm{ml}$ of $1 \% \mathrm{CoCl}_{2}$ (fig 5). Challenge test with pollens of Japanese cedar also positive (immediate type). Specific antibodies against pollens of Japanese cedar and Dermatophagoides were positive. Eosinophilia and high IgE were also detected. Patch test with cobalt was positive at 72 hours.

Case 19-Born in 1926, a smoker since age 21 for 16 years. Had worked in a steel industry for 17 years and had inhaled an enormous amount of sand dust for one year. Then employed as a press operator in the hard metal industry at age 46. Had been exposed to hard metal as a press operator for five years and then as a shaper for four years. The chest radiograph taken in 1977 (fig 6) showed small opacities in all lung fields (profusion 2/2, shape and size s/q). In 1981 rounded opacities in the upper lung fields were increased and he was admitted to the National Kinki Chuo Hospital for Chest Diseases. Had no 

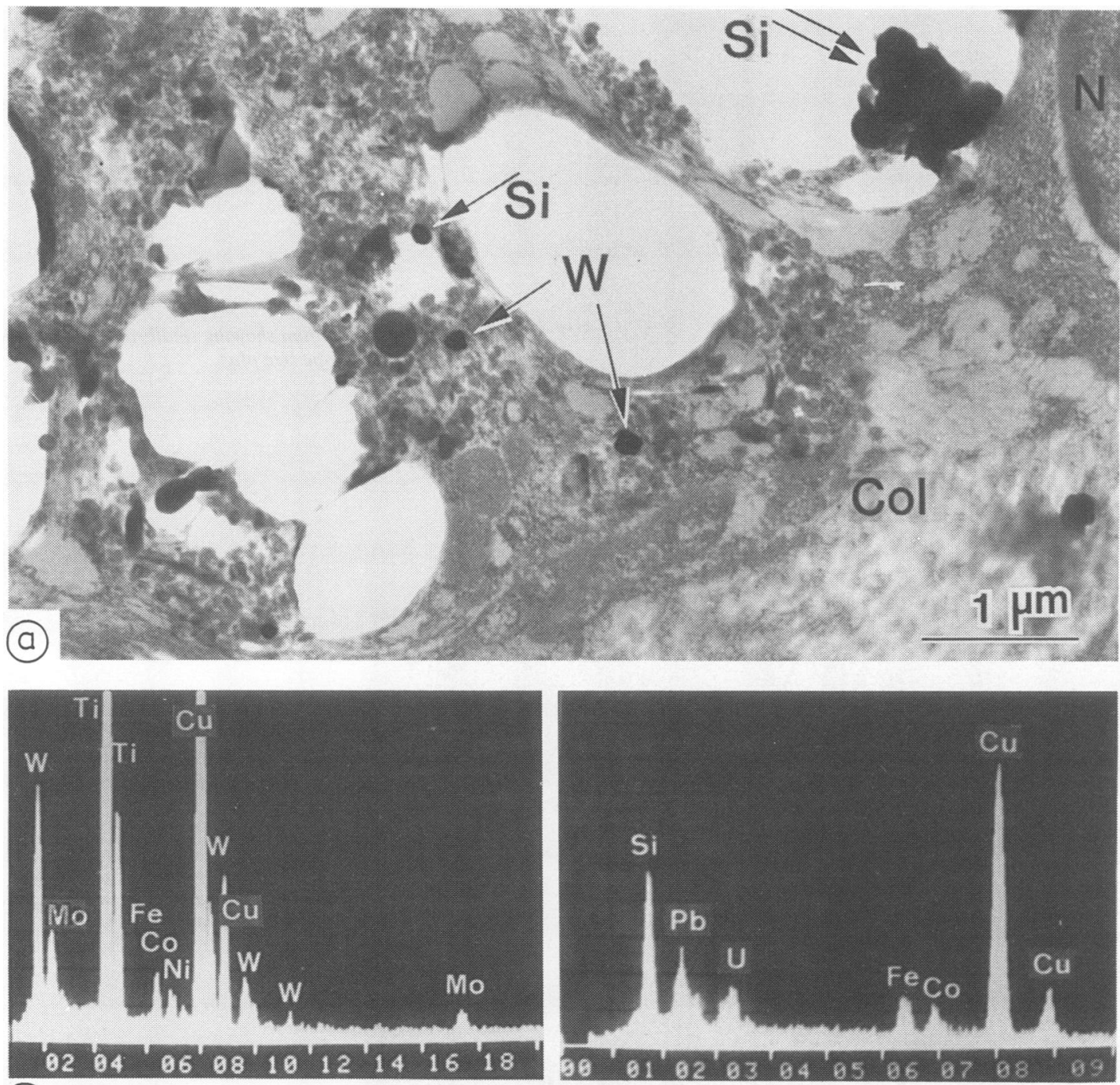
(b)

Fig 11 (a) Electron micrograph of alveolar macrophages in case 20. Particles of tungsten (W) and silicon (Si) with small quantity of iron and cobalt are included. $N$ : nucleus, col: collagen fibres. (b) Spectrum of $x$ ray microprobe analysis on particles incorporated in a phagosome of a dust cell. Characteristic components of hard metal, W, Mo, Ti, Co, and Ni are included. (Cu spectrum from supporting grid.) (c) X ray spectrum of Si particles indicated by double arrows in ( $a$ ) ( $P b$ and $U$ spectra from staining medium, Cu from supporting grid.)

respiratory symptoms. Neither finger clubbing nor rales were noted. Pulmonary function tests showed a restrictive ventilatory disorder and a decrease in diffusion capacity: TLC, 4.191; VC, 2.531; \%VC, $71.6 \%$; RV, 1.66l; RV/TLC, 39.6\%; FVC, 2.601; FEV $_{1}, 2.561$; $\mathrm{FEV}_{1} \%, 98 \cdot 6 \%$, $\mathrm{D}_{\mathrm{L}} \mathrm{CO}, 14.31 / \mathrm{min} / \mathrm{mm} \mathrm{Hg} ; \% \mathrm{D}_{\mathrm{L}} \mathrm{CO}, 57 \cdot 2 \%$. Immunoglobulins, tissue antibodies, common RASTs, and blood chemistry showed no abnormalities. Lung biopsy specimens obtained in the right $S_{8}$ and $S_{9}$ showed perivascular and peribronchial fibrosis with black particles and peribronchiolar lymphoid cell aggregation (fig 7). No interstitial pneumonitis. $X$ ray microanalysis of deposited particles showed that they consisted of several elements of hard metal (tungsten, titanium, cobalt, nickel) and some minerals including quartz, mica, etc (fig 8). Removed from the initial hard metal work he became a guard in the industry. No changes in chest radiographs 
were observed afterwards. Respiratory symptoms and histological finding were not consistent with those seen in hard metal workers with interstitial pneumonitis. ${ }^{1423-27}$ Case diagnosed as having pneumoconiosis due to minerals inhaled in the steel industry.

Case 20-Born in 1947, with a history of infectious asthma and pneumonia during childhood. After graduation from college, became an engineer in the hard metal industry. Worked as a shaper for first six months then ground sintered hard metal, dry and with no ventilation, two hours a day for two and a half years, using mainly caborundum grinding wheels. Then engaged in mixing powder for six months. Later transferred to non-dusty work. In 1981 chest radiograph (fig 9) showed small round opacities in all lung fields (profusion 1/2, shape and size $\mathrm{p} / \mathrm{q})$. He was symptom free and on initial physical examination no abnormality was seen. In 1982 admitted to hospital. Results of blood tests showed nothing abnormal and pulmonary function tests were within normal range. Lung biopsy specimens obtained from right $S_{\mathbf{8}}$ and $S_{9}$ showed peribronchiolar fibrosis with a slight dust deposition and thickening of arteriole intima (fig 10). Interstitial pneumonitis was not seen. $X$ ray microanalysis of particles in fibrotic region showed presence of hard metal elements, such as tungsten, titanium, molybdenum, cobalt, and nickel, and of silicon accompanied by iron and cobalt. Particles containing silicon were probably fragments derived from the grinding wheels. Mica was also detected (see fig 11). No change in respiratory symptoms, chest radiographs, or pulmonary function after discharge from hospital.

Respiratory symptoms, pulmonary function, chest radiographs, and histological findings not consistent with those in workers who have developed interstitial pneumonitis in the hard metal industry. ${ }^{1423-27}$ This case suspected of having had pulmonary fibrosis caused by minerals generated from grinding wheels, since it was similar to those reported by Rüttner and Furrer. ${ }^{30}$

Case 21-Born in 1935, developed pulmonary tuberculosis at age 13. After treatment with antituberculous drugs for two years the disease was arrested. When aged 24 started working in shaping and mixing of hard metal shortly after graduation from college. Ten years later became a supervisor and was no longer exposed to hard metal. A chest radiograph taken in 1981 showed small rounded opacities in bilateral upper and middle lung fields (profusion 1/1, shape and size $\mathrm{p} / \mathrm{q})$. No respiratory symptoms noted and rales were not heard. Pulmonary function tests were normal. Declined a lung biopsy and so an accurate diagnosis could not be made. Interstitial pneumonitis was not suspected.

\section{References}

${ }^{1}$ Ohi T. On the pneumoconiosis among workers in a hard cutting tool factory. Journal of Science of Labour 1954;30:317-24.

${ }^{2}$ Shirasaki T. Pneumoconiosis in the tungsten-carbide tool industry. Internal Medicine 1969;24:377-82.

${ }^{3}$ Yamamoto T, Ogima I. A case of diffuse interstitial pneumonitis in a tungsten carbide worker. Japanese Journal of Chest Disease 1973;32:64-8.

${ }^{4}$ Kitamura H, Kitamura H, Tozawa T, Kimura Y. Cemented tungsten carbide pneumoconiosis. Acta Pathologica Japonica 1978;28:921-35.

${ }^{5}$ Yokoyama K, Kusaka Y, Yamamoto S, Sera Y. A case of interstitial pneumonitis due to hard metal (stellite). Japanese Journal of Thoracic Diseases 1983;21:1096-1100.

${ }^{6}$ Wada M, Satsuta H, Iwai K, Shiozawa M. A case of tungsten pneumoconiosis associated with secondary pneumothorax. Japanese Journal of Chest Disease 1979;38:663.

${ }^{7}$ Ikeda M, Ohtsuji H, Yamashita N, Nishitani Y. Two cases of respiratory irritation presumably due to cobalt metal dust. Japanese Journal of Industrial Health 1971;13:54-5.

${ }^{8}$ Ebihara I. A clinical case of occupational cobalt asthma. Journal of Science of Labour 1983;59:321-5.

${ }^{9}$ Kusaka Y, Kuwabara O, Kitamura H. A case of diffuse lung disease associated with lung cancer in a hard metal worker.
Japanese Journal of Thoracic Diseases 1984;22:804-8.

${ }^{10}$ Kusaka Y, Sugimoto K, Seki Y, et al. Bronchopulmonary diseases due to hard metal dust: viewpoint of clinical examinations. Japanese Journal of Industrial Health 1982;24:636-48.

${ }^{11}$ Kusaka Y, Ichikawa Y, Sugimoto K, Goto S. Bronchopulmonary diseases due to hard metal dust: viewpoint of dust measurement. Japanese Journal of Industrial Health 1983;25:155-60.

${ }^{12}$ Kusaka Y. Hard metal asthma: a case of allergic bronchial asthma and contact dermatitis due to cobalt. Japanese Journal of Thoracic Diseases 1983;21:582-6.

${ }^{13}$ Coates EO, Sawyer HJ, Rebuck JW, Kvale PA, Sweat LW. Hypersensitivity bronchitis in tungsten carbide workers. Chest 1973;64:390.

${ }^{14}$ Davison AG, Haslam PL, Corrin B, et al. Interstitial lung disease and asthma in hard-metal workers: bronchoalveolar lavage, ultrastructural, and analytical findings and results of bronchial provocation tests. Thorax 1983;38:119-28.

${ }^{15}$ Delahant AB. An experimental study of the effects of rare metals on animal lungs. Archives of Industrial Health 1955;12:116-20.

${ }^{16}$ Schepers GWH. The biological action of particulate cobalt metal, tantalum oxide, cobalt oxide, tungsten metal, tungsten carbide and carbon, tungsten carbide and cobalt. Archives of Industrial Health 1955;12:121-46.

${ }^{17}$ Kaplun ZS, Mezencewa NW. Experimental study on the toxic effect of dust in production of sintered metals. J Hyg Epidemiol Microbiol Immunol 1960;4:390-9.

${ }^{18}$ Kerfoot EJ, Frederick WG, Domeier E. Cobalt metal inhalation studies on miniature swine. Am Ind Hyg Assoc J 1975;36:17-25.

${ }^{19}$ Wehner AP, Busch RH, Olson RJ, Craig DK. Chronic inhalation of cobalt oxide and cigarette smoking by hamsters. Am Ind Hyg Assoc $J$ 1977;38:338-46.

${ }^{20}$ International Labour Office. International classification of radiographs of pneumoconioses. Geneva: ILO, 1980.

${ }^{21}$ Fregert S, Bandmann H-J. Patch test. Berlin: Springer-Verlag, 1975:24.

${ }^{22}$ Roto P. Asthma, symptoms of chronic bronchitis and ventilatory capacity among cobalt and zinc production workers. Scand $J$ Work Environ Health 1980;6, suppl 1:1-49.

${ }^{23}$ Coates EO, Watson JHL. Diffuse interstitial lung disease in tungsten carbide workers. Ann Intern Med 1971;75:709-16.

${ }^{24}$ Scherrer M, Parambadathumalail A, Bürki H, Senn A, Zürcher R. Drei Fälle von Hartmetallstaublunge. Schweitz Med Wochenschr 1970;100:2251-5.

${ }^{25}$ Meyer PD, Stoeckel C, Geist T, Le Bouffant L, Roegel E. A propos de trois nouveaux cas de fibrose pulmonaire chez des affûteurs d'outils renforcés au carbure de tungstène. PoumonCoeur 1981;37:165-75.

${ }^{26}$ Konietzko H, Fleischmann R, Reill G, Reinhard U. Lungenfibrosen bei der Bearbeitung von Hartmetallen. Dtsch Med Wochenschr 1980;105:120-3.

${ }^{27}$ Hartung M, Schaller K-H, Brand E. On the question of the pathogenic importance of cobalt for hard metal fibrosis of the lung. Int Arch Occup Environ Health 1982;50:53-7.

${ }^{28}$ Ichikawa Y, Kusaka Y, Goto S. Biological monitoring of cobalt exposure based on cobalt concentrations in blood and urine. Int Arch Occup Environ Health 1985;55:269-76.

${ }^{29}$ Chan-Yeung M. Fate of occupational asthma. Am Rev Respir Dis 1977;116:1023-9.

${ }^{30}$ Rüttner JR, Furrer CF. Die Pathologie der sogenannten "Hartmetallstaub-Lunge» und vergleichende LungenstaubAnalysen. Z Unfallmed Berufskr 1982;75:191-7.

${ }^{31}$ Bech AO, Kipling MD, Heather JC. Hard metal disease. Br J Ind Med 1962;19:239-52.

${ }^{32}$ Lundgren KD, Öhman H. Pneumokoniose in der Hartmetallindustrie. Virchows Arch 1954;325:259-84.

${ }^{33}$ Bartl F, Lichtenstein ME. Tungsten carbide pulmonary fibrosisa case report. Am Ind Hyg Assoc J 1975;37:668-70.

${ }^{34}$ Sprince NL, Chamberlin RI, Hales CH, Weber AL, Kazemi H. Respiratory disease in tungsten carbide production workers. Chest 1984;86:549-57.

${ }^{35}$ Miller CW, Davis MW, Goldman A, Wyatt JP. Pneumoconiosis in the tungsten-carbide tool industry. Arch Ind Hyg 1953;8:453-65. 